\title{
CYCLOOCTATETRAENYL NEODYMIUM(III) BROMIDE AND CYCLOOCTATETRAENYL NEODYMIUM(III) IODIDE
}

\section{by}

D. G. Karraker and M. P. Palm*

\section{Savannah River Laboratory}

E. I. du Pont de Nemours \& Co. Aiken, South Carolina 29801

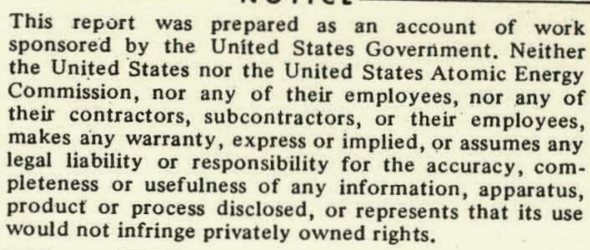

A paper proposed for presentation at the 25th Annual Southeastern Regional Meeting of the American Chemical Society at Charleston, South Carolina, on November 7-9, 1973.

This paper was prepared in connection with work under Contract No. AT (07-2)-1 with the U. S. Atomic Energy Commission. By acceptance of this paper, the publisher and/or recipient acknowledges the U. S. Government's right to retain a nonexclusive, royalty-free license in and to any copyright covering this paper, along with the right to reproduce and to authorize others to reproduce all or any part of the copyrighted paper.

* AEC Undergraduate Research Trainee from S. C. State College, Orangehurg, S. C. 


\section{DISCLAIMER}

This report was prepared as an account of work sponsored by an agency of the United States Government. Neither the United States Government nor any agency Thereof, nor any of their employees, makes any warranty, express or implied, or assumes any legal liability or responsibility for the accuracy, completeness, or usefulness of any information, apparatus, product, or process disclosed, or represents that its use would not infringe privately owned rights. Reference herein to any specific commercial product, process, or service by trade name, trademark, manufacturer, or otherwise does not necessarily constitute or imply its endorsement, recommendation, or favoring by the United States Government or any agency thereof. The views and opinions of authors expressed herein do not necessarily state or reflect those of the United States Government or any agency thereof. 


\section{DISCLAIMER}

Portions of this document may be illegible in electronic image products. Images are produced from the best available original document. 
CY.CLOOCTATETRAENYL NEODYMIUM(III) BROMIDE

AND CYCLOOCTATETRAENYL NEODYMIUM(III) IODIDE*

by

D. G. Karraker and M. P. Palm**

Savannah River Laboratory

E. I. du. Pont de Nemours \& Co.

Aiken, S. C. 29801

ABSTRACT - Cyclooctatetraenyl neodymium(III) bromide [Nd(COT)Br,

where $\left.\mathrm{COT}=\mathrm{C}_{8} \mathrm{H}_{8}^{-2}\right]$ and $\mathrm{Nd}\left(\mathrm{COII}^{\prime}\right) \mathrm{I}$ were prepared by the reaction of anhydrous $\mathrm{NaBr}_{3}$ and $\mathrm{NaI}_{3}$ with $\mathrm{K}_{2} \mathrm{COT}$ in tetrahydrofuran (THF) solut1on. Nd(COT)Br. 3THF was isolated from the THF solution as a green solid that was extremely reactive to both water and air. The $\mathrm{Nd}^{3+}$ Ion in $\mathrm{Nd}(\mathrm{COT}) \mathrm{Br} \cdot 3 \mathrm{THF}$ had two regions of temperature-dependent magnetic susceptibility: $\mu_{\text {eff }}=2.37 \mu_{B}$ from 2.2 to $17^{\circ} \mathrm{K}$, and $\mu_{\text {eff }}=$ $2.83 \mu_{\mathrm{B}}$ from 20 to $48^{\circ} \mathrm{K}$. Preliminary studies on the Nd(COT)I.4THF indicate chemical properties similar to Nd(COT)Br.3THF. Both compounds are analogous to the dimeric $[\mathrm{Ln}(\mathrm{COT}) \mathrm{Cl}]_{2}$ compounds reported by Mares, Hodgson, and Streitwieser [ $\underline{\mathrm{J}}$. Organometal. Chem. 28, $C 24(1971)]$

* The information contained in this article was developed during the course of work under Contract AT(07-2)-1 with the U. S. Atomic Energy Commission

** AEC Undergraduate Research Trainee from S. C. State College, Orangeburg, S. C. 
CYCLOOCTATETRAENYL NEODYMIUM(III) BROMIDE AND CYCLOOCTATETRAENYL NEODYMIUM(III) IODIDE

by

D. G. Karraker and M. P. Palm Savannah River "Laboratory

E. I. du Pont de Nemours \& Co. Aiken, S. C. 29801

INTRODUCTION

Mares, Hodgson, and Streitwieser $(1,2)$ have prepared and studied lanthanide cyclooctatetraenyl chlorides [Ln(COT)C1 2 2THF] 2 $\left(\mathrm{Ln}=\mathrm{Ce}^{3+}, \mathrm{Pr}^{3+}, \mathrm{Nd}^{3+}, \mathrm{Sm}^{3+} ; \mathrm{COT}=\mathrm{C}_{8} \mathrm{H}_{8}=; \mathrm{THF}=\mathrm{C}_{4} \mathrm{H}_{8} \mathrm{O}\right)$, air- and water-sensitive compounds: The ceric structure involves a chloride bridge between the two $\mathrm{Ce}^{3+}$, ions in the dimer ${ }^{(3)}$ (Figure 1). Such a structure has the possibility of cooperative magnetic effects through the bridging chlorides, but the possibility might be improved for the bromide or iodide analogues. The synthesis and magnetic susceptibility measurements on $\mathrm{Nd}(\mathrm{COT}) \mathrm{I} \cdot \mathrm{xTHF}$ and Nd(COT) $B r \cdot x T H F$ are presented in this paper.

(1) F. Mares, K. O. Hodgson, and A. Streitwieser, Jr., J. Organometal. Chem. 28, C24(1971).

(2) K, n. Hndgson, Ph.D, thesis, University of California, Berkeley (1972).

(3) K. 0. Hudgsull and K. N. Raymond, Inorg. Chem. 11, 171 (1972). 


\section{EXPERIMENTAL}

The purification of solvents, analytical methods, magnetic susceptibility measurements, x-ray diffraction, etc. were performed as previously described. (4) The compounds were synthesized and purified in a dry argon atmosphere.

(4) D. G. Karraker, J. A. Stone, E. R. Jones, Jr., and N. Edelstein, JACS $\underline{92}, 4841$ (1970).

Cyclooctatetraenyl was vacuum distilled before use. Anhydrous $\mathrm{NdBr}_{3}$ and $\mathrm{NdI}_{3}$ were prepared by reacting $\mathrm{Nd}$ metal with $\mathrm{HgBr}_{2}$ or $\mathrm{HgI}_{2}$ in a sealed, evacuated glass tube at $350^{\circ} \mathrm{C}$.

$\mathrm{Nd}(\mathrm{COT}) \mathrm{I} \cdot \mathrm{xTHF}$ was prepared by adding a stoichiometric quantity of $\mathrm{NdI}_{3}$ to a -10 to $-20^{\circ} \mathrm{C}$. THF solution of $\mathrm{K}_{2} \mathrm{COT}$. The solution was allowed to warn to room temperature and then stirred for 4 to 20 hours. The reaction mixture was filtered, and the filtrate was vacuum-evaporated to recover the light green product. Calculated for $\mathrm{Nd}(\mathrm{COT}) \mathrm{I} \cdot 4 \mathrm{THF}$ : Nd 21.8, I 19.2. Found: Nd 22.1, I $19.2 ; \mathrm{Nd} / \mathrm{I}$ mole ratio, 1.009 .

Attempts to prepare $\mathrm{Nd}(\mathrm{COT}) \mathrm{Br} \cdot x \mathrm{THF}$ by the same method produced a mixture of $\mathrm{KNd}(\mathrm{COT})_{2} \cdot x \mathrm{THF}$ and $\mathrm{Nd}(\mathrm{COT}) \mathrm{Br} \cdot x \mathrm{THF}$. This mixture was dissolved in THF and stirred at room temperature with excess $\mathrm{NdBr}_{3}$ for 3 or 4 days and then filtered; the filtrate was vacuum-evaporated to recover the light green $\mathrm{Nd}(\mathrm{COT}) \mathrm{Br} \cdot x \mathrm{THF}$. Calculated for $\mathrm{Nd}(\mathrm{COT}) \mathrm{Br} \cdot 3 \mathrm{THF}$ : $\mathrm{Nd} \cdot 26.3, \mathrm{Br} 14.6$. Found: 
Nd 25.1, $\mathrm{Br} 13.8 ; \mathrm{Nd} / \mathrm{Br}$ mole ratio, 1.008 . The differences from the calculated composition are attributed to occluded solvent in the sample.

The chemical properties of both compounds are similar to those of the $[\operatorname{Ln}(\mathrm{COT}) \mathrm{Cl} 1 \cdot 2 \mathrm{THF}]_{2}$ compounds. $(1,2)$ They are extremely air- and moisture-sensitive, soluble in THF and diglyme [bis(2methoxyethyl) ether], insoluble in benzene, toluene, and hexane, and decomposed by ethyl alcohol.

\section{RESULTS}

X-ray diffraction data for powdered samples of $\mathrm{Nd}(\mathrm{COT}) \mathrm{Br}$. $3 \mathrm{THF}$ and $\mathrm{Nd}(\mathrm{COT}) \mathrm{I} \cdot 4 \mathrm{THF}$ are shown in Table I, with diffraction data for $\mathrm{KNd}(\mathrm{COT})_{2} \cdot \mathrm{ZTHF}$ included for comparison. Although the data for Nd(COT) Br-3THF are not particularly good, the differences in the powder patterns indicate three different materials.

The magnetic susceptibility results from 2.2 to $50^{\circ} \mathrm{K}$ for $\mathrm{Nd}(\mathrm{COT}) \mathrm{I} \cdot 3 \mathrm{THF}$ and $\mathrm{Nd}(\mathrm{COT}) \mathrm{Br} \cdot 4 \mathrm{THF}$ are summarized in Table II and shown graphically in Figures 2 and 3. Both compounds have strong temperature-dependent (Curie-Weiss) paramagnetism, and essentially the same in magnetic properties. 


\section{DISCUSSION}

These preliminary studies of $\mathrm{Nd}(\mathrm{COT}) \mathrm{Br}$ and $\mathrm{Nd}(\mathrm{COT}) \mathrm{I}$ show no evidence for cooperative magnetic effects above $2.2^{\circ} \mathrm{K}$. This can be attributed either to a different molecular structure for the bromide and iodide than the bridged chloride dimer, or to a lack of exchange; even with a favorable geometry. Both are credible; the increase in solvation from the two per $\mathrm{Nd}^{3+}$ ion in [ $\mathrm{Nd}(\mathrm{COT})$ $\mathrm{C} 1 \cdot 2 \mathrm{THF}]_{2}$ to three for $\mathrm{Nd}(\mathrm{COT}) \mathrm{Br} \cdot 3 \mathrm{THF}$ and four for $\mathrm{Nd}(\mathrm{COT}) \mathrm{I} \cdot 4 \mathrm{THF}^{\prime}$ suggests differences in structures that could require the increased solvation for shielding of the $\mathrm{Nd}^{3+}$ ion. The trivalent lanthanide ions are strongly electronegative ions - very "hard" ions, to use a popular expression - and do not show any marked deviation from normal magnetic behavior until very low temperatures are reached. For example, $\mathrm{GdCl}_{3}$ has a Curie point at $2.2^{\circ} \mathrm{K},{ }^{(5)}$ and $\mathrm{NdCl}_{3}$ has a still lower Curie point, $1.745^{\circ} \mathrm{K} .{ }^{(6)}$ The possibility of magnetic exchange depends heavily on the donation of electron density by the electron-rich COT dianinn and the bromide or

(5) W. P. Wolf, M. J. M. Leask, B. W. Mangum and A. F. G. Wyatt, J. Phys. Sci. Japan Suppl. B-I, 487 (1961).

(6) J. C. Eisenstein, R. P: Hudson and D. W. Mangum, Phys. Letters 12, 5, (1964).

iodide ion, and could still be insufficient at the lowest temperatures reached in this study, 2.2 to $2.3^{\circ} \mathrm{K}$. 
The observed magnetic susceptibilities are consistent with the predicted ${ }^{(7)}$ magnetism for a $\mathrm{J}=9 / 2$ ion in a low symmetric site by either of two explanations.

(7) K. R. Lea, M. J. M. Leask; and W. P. Wolf, J. Phys. Chem. Solids 23, 1381 (1962).

The observed magnetic susceptibility shows two levels, one 10 to 15 $\mathrm{cm}^{-1}$ above the ground level. In $\mathrm{O}_{\mathrm{h}}$ site symmetry for an $\mathrm{Nd}^{3+}$. ion, the lowest crystal field level will be either a $\Gamma_{6}$ (doublet) or a $\Gamma_{8}$ (quartet). In a lower symmetry than $O_{h}$, the $\Gamma_{8}$ level would split into $\Gamma_{6}$ or $\Gamma_{7}$ levels. Either a $\Gamma_{6}$ lowest level, with the (split) $\Gamma_{8}$ level 10 to $15 \mathrm{~cm}^{-1}$ higher, or the $\Gamma_{8}$ level split by a strong crystal field into two leveis 10 to $15 \mathrm{~cm}^{-1}$ apart is a possible explanation for the magnetic susceptibility results.

Despite the lack of success in the major purpose of this investigation, $\mathrm{Nd}(\mathrm{COT}) \mathrm{Br} \cdot 3 \mathrm{THF}$ and $\mathrm{Nd}(\mathrm{COT}) \mathrm{I} \cdot 4 \mathrm{THF}$ are compounds of considerable interest, both for possible covalent effects in their bonding, and for their potential as intermediates in the synthesis of other neodymium organo-metallic compounds. 
TABLE I

PARTIAL X-RAY DIFFRACTION DATA

$\mathrm{Nd}(\mathrm{COT}) \mathrm{Br} \cdot 3 \mathrm{THF} \quad \mathrm{Nd}(\mathrm{COT}) \mathrm{I} \cdot 4 \mathrm{THF} \quad \mathrm{KNd}(\mathrm{COT})_{2} \cdot 2 \mathrm{THF}$

\begin{tabular}{|c|c|c|c|c|c|c|c|c|}
\hline $2 \theta$ & $\mathrm{d}, \AA$ & $I$ & $2 \theta$ & $d, \AA$ & I & $2 \theta$ & $d, \AA$ & \\
\hline \multirow[t]{4}{*}{11.49} & 7.70 & $M$ & 11.44 & 7.73 & M & 10.17 & 8.69 & $M$ \\
\hline & & & 12.44 & 7.12 & M & 10.82 & 8.18 & $\mathrm{~s}$ \\
\hline & & & 14.29 & 6.20 & W & 12.42 & 7.13 & M \\
\hline & & & & & & 12.97 & 6.83 & $\mathbf{S}$ \\
\hline \multirow[t]{6}{*}{15.99} & 5.54 & $S$ & & & & 14.42 & 6.14 & $w$ \\
\hline & & & 17.24 & 5.14 & w & 14.97 & 5.92 & M \\
\hline & & & 18.14 & 4.89 & W & 15.62 & 5.67 & $w$ \\
\hline & & & & & & 16.19 & 5.48 & $W$ \\
\hline & & & 20.99 & 4.23 & $W$ & 16.77 & 5.29 & W \\
\hline & & & & & & 19.47 & 4.56 & $w$ \\
\hline \multirow[t]{3}{*}{22.89} & 3.89 & $M$ & 22.84 & 3.89 & $w$ & 21.92 & 4.06 & \\
\hline & & & 23.39 & 3.80 & W & 24.02 & 3.71 & $w$ \\
\hline & & & 24.54 & 3.63 & W & 26.67 & 3.34 & n \\
\hline \multirow[t]{3}{*}{25.09} & 3.55 & $M$ & 25.19 & 3.53 & $w$ & 28.72 & 3.11 & $W$ \\
\hline & & & & & & 30.62 & 2.92 & \\
\hline & & & 27.24 & 3.27 & M & 31.42 & 2.85 & \\
\hline 28.69 & 3.11 & $w$ & 30.14 & 2.96 & $w$ & 32.89 & 2.72 & \\
\hline \multirow[t]{2}{*}{30.99} & 2.89 & $W$ & 31.14 & 2.87 & $w$ & 34.22 & 2.62 & \\
\hline & & & 31.69 & 2.82 & $w$ & 36.92 & 2.43 & \\
\hline 32.44 & 2.76 & $w$ & 32.14 & 2.78 & w & 37.77 & 2.38 & $r$ \\
\hline 34.94 & 2.57 & VW & 35.69 & 2.52 & w & 39.22 & 2.30 & 1 \\
\hline \multirow[t]{2}{*}{36.69} & 2.45 & M & 38.74 & 2.32 & w & 40.87 & 2.21 & \\
\hline & & & .39 .54 & 2.28 & w & 42.77 & 2.11 & \\
\hline \multirow[t]{2}{*}{411.99} & 2.200 & W & $41 . \dot{9} 4$ & 2.15 & $W$ & 44.32 & 2,04 & \\
\hline & & & & & & 45.57 & 1.99 & \\
\hline
\end{tabular}

$46.04 \quad 1.97 \mathrm{~W}$

TABLE II

MAGNETIC SUSCEPTIBILITIES FOR ND(III)-COT COMPOUNDS

\begin{tabular}{|c|c|c|c|c|}
\hline Compound & Temp: Raiıge, & $\begin{array}{c}c^{a} \\
\text { emu } /{ }^{\circ} K \text { mole }\end{array}$ & $\begin{array}{l}\theta^{a}, \\
{ }^{\circ}{ }_{K}\end{array}$ & $\begin{array}{c}\mu_{\text {eff }} \\
\mu_{\mathrm{B}} / \text { molecule } \\
\end{array}$ \\
\hline \multirow[t]{2}{*}{$\mathrm{Nd}(\mathrm{COT}) \mathrm{Br} \cdot 3 \mathrm{THF}$} & $0-1.5$ & 0.70 & 0.84 & 2.37 \\
\hline & $20-90$ & 1,00 & 7,0 & 2.83 \\
\hline \multirow[t]{2}{*}{$\mathrm{Nd}(\mathrm{COT}) \mathrm{I} \bullet 4 \mathrm{THF}$} & $0-18$ & 0.70 & 0.2 & 2.36 \\
\hline & $20-70$ & 0.90 & 5.1 & 2.69 \\
\hline
\end{tabular}

a. From the Curie-Weiss expression, $X=C /(T+\theta)$

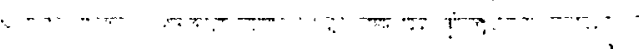

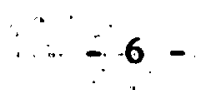



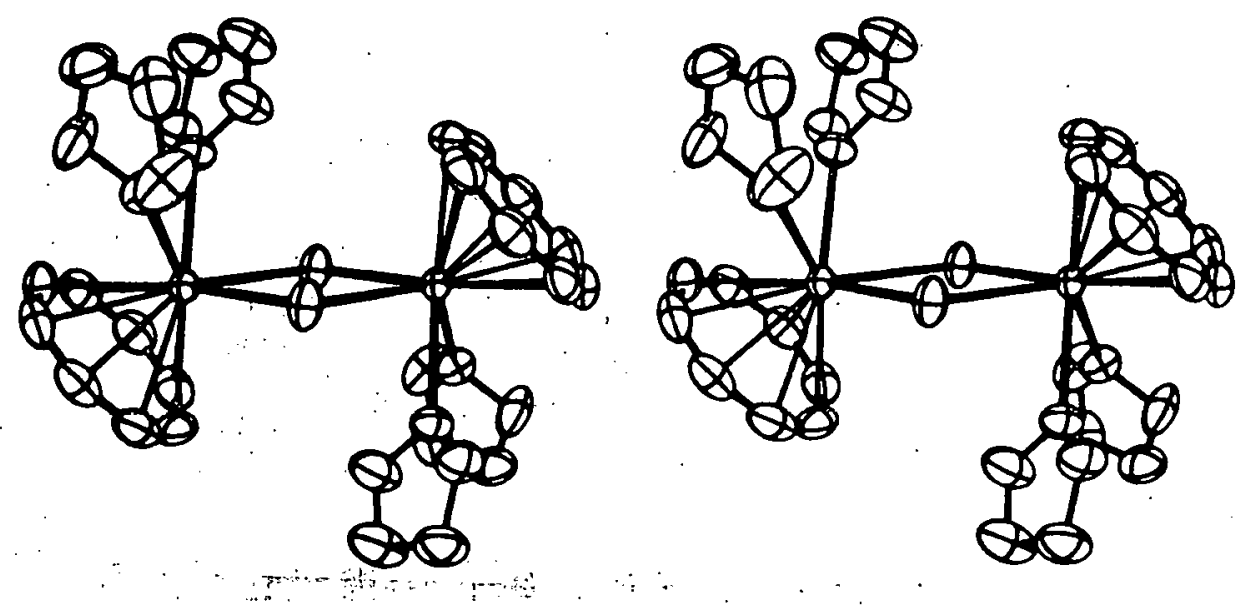

Figure 1. A stereoscopic diagram of the $\left[\mathrm{Ce}\left(\mathrm{C}_{8} \mathrm{H}_{8}\right) \mathrm{Cl} \cdot 2 \mathrm{C}_{4} \mathrm{H}_{8} 0\right]_{2}$. complex. Thermal ellipsoids are drawn at the $40 \%$ probability contour. Reference 3.

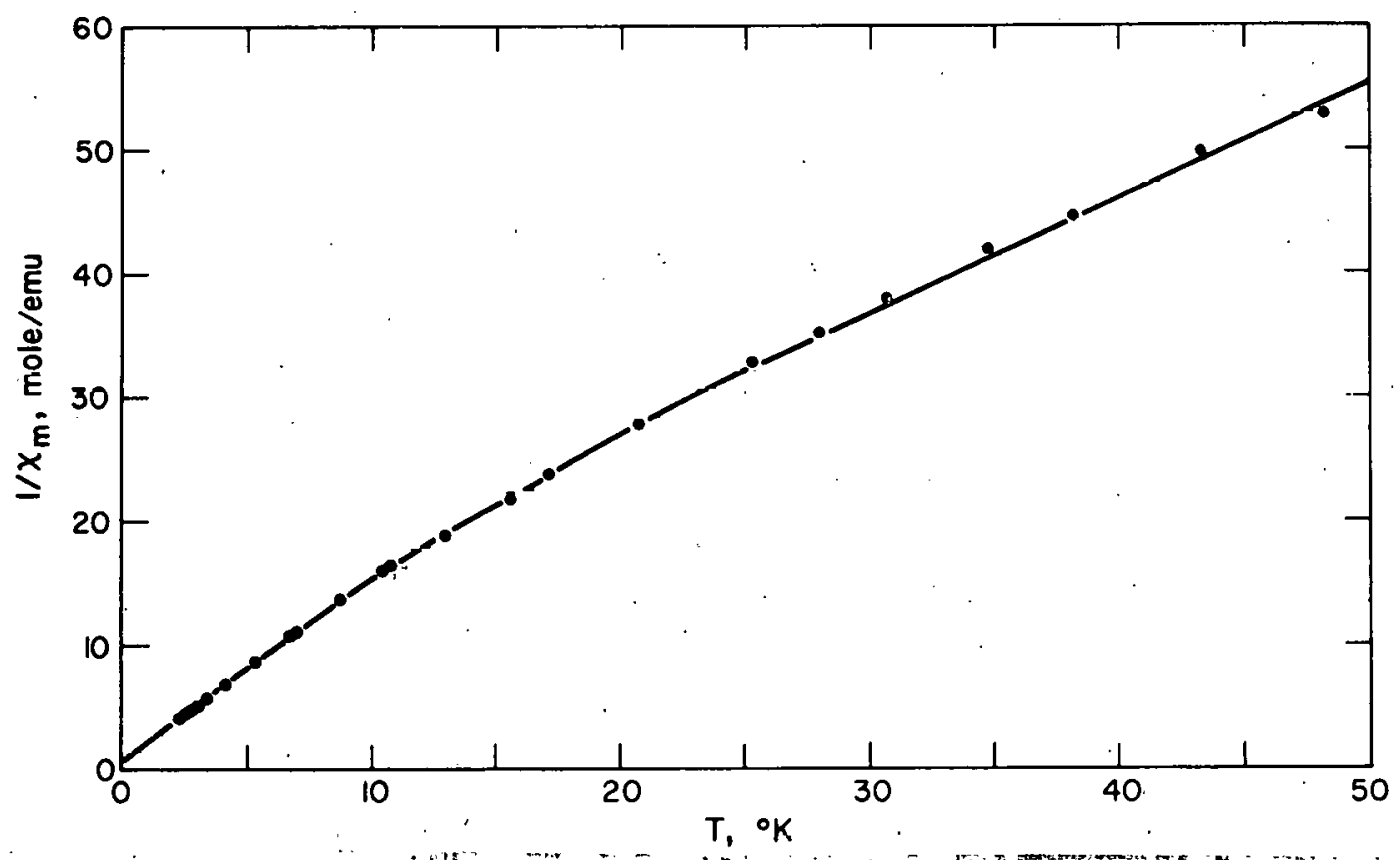

Figure 2. Inverse Magnetic Susceptibility of $\mathrm{Nd}(\mathrm{COT}) \mathrm{Br} \cdot 3 \mathrm{THF}$ 


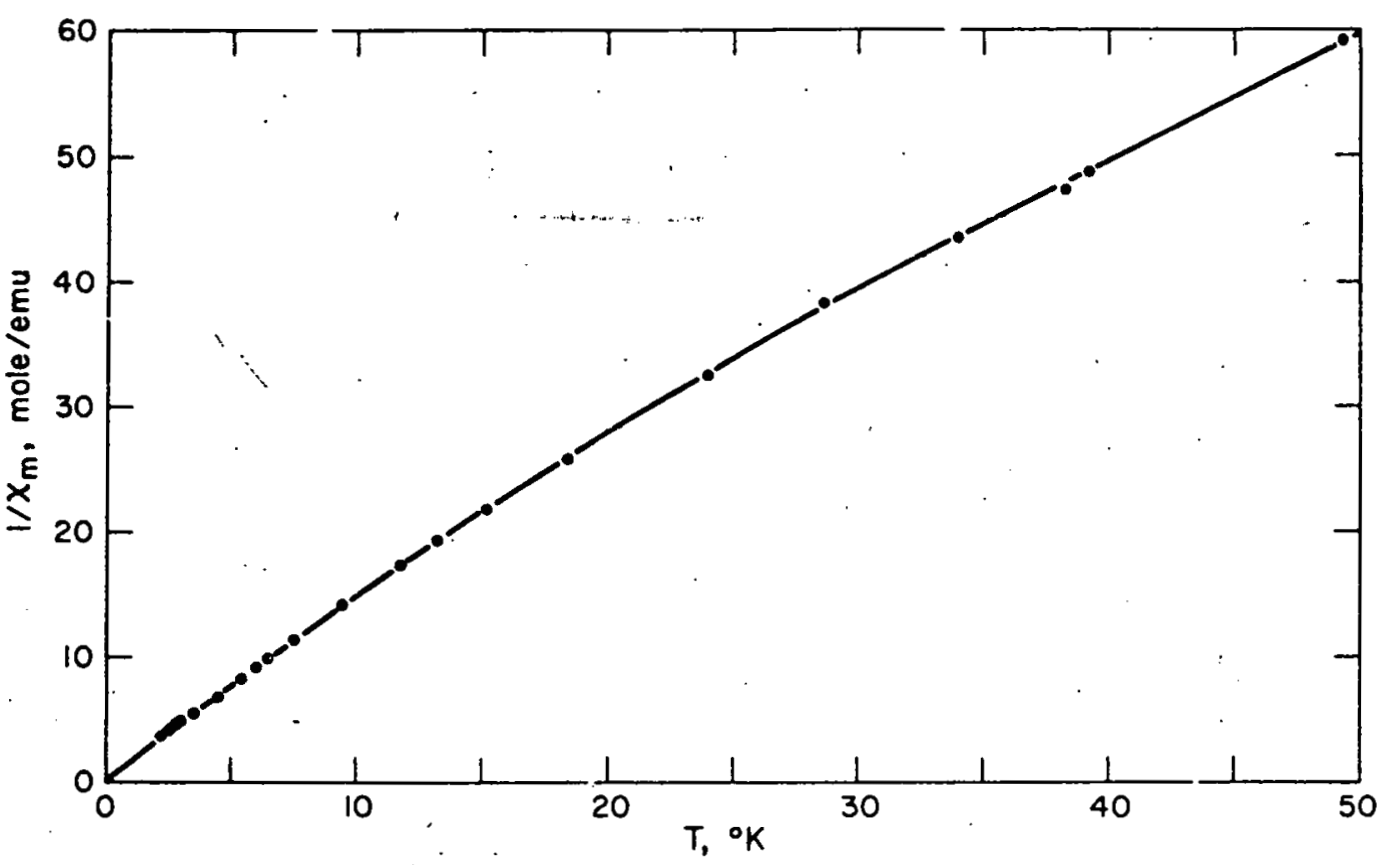

Figure 3. Inverse Magnetic Susceptibility of $\mathrm{Nd}(\mathrm{COT}) \mathrm{I} \cdot 4 \mathrm{THF}$ 